\title{
Impaired miR449a-induced downregulation of Crhr1 expression in low-birth-weight rats
}

\author{
Takahiro Nemoto, Yoshihiko Kakinuma and Tamotsu Shibasaki \\ Department of Physiology, Nippon Medical School, 1-1-5 Sendagi, Bunkyo-ku, Tokyo 113-8602, Japan
}

Correspondence should be addressed to T Nemoto

Email

taknemo@nms.ac.jp

\begin{abstract}
Low birth weight (LBW) is related to increased incidence of common cardiovascular and metabolic disorders, and psychopathologies later in life. Recent studies have suggested that maternal malnutrition affects fetal hypothalamic-pituitary-adrenal (HPA) axis programing although the mechanism is unknown. We demonstrated that LBW offspring delivered from malnourished dams showed prolonged elevated plasma corticosterone concentrations when compared with those of normal-birth-weight (NBW) offspring and impaired downregulation of corticotropin-releasing factor receptor type 1 (CRF-R1, Crhr1) in the anterior pituitary in restraint. Restraint increased expression of miR449a, which we had previously demonstrated to be involved in Crhr1 downregulation, in the anterior pituitary and serum exosomal miR449a contents through glucocorticoids in NBW offspring, but not in LBW offspring. Although plasma corticosterone concentrations were higher at $2000 \mathrm{~h}$ than at $0800 \mathrm{~h}$ in both LBW and NBW offspring, they were significantly higher in LBW offspring than in NBW offspring at 2000 and $0200 \mathrm{~h}$. There were no significant diurnal changes in miR449a expression levels in the anterior pituitary of either NBW or LBW offspring, but the expression was significantly lower in LBW offspring than in NBW offspring at 1400, 2000, and $0200 \mathrm{~h}$. The expression levels of GAS5, which inhibits glucocorticoid receptor (GR) binding to glucocorticoid-responsive element, in the anterior pituitary of LBW offspring were elevated when compared with those of NBW offspring. The downregulation of GR found in NBW offspring did not occur in restrained LBW offspring. These results indicate that impaired miR449a expression, probably induced by increased GAS5 expression, causes dysregulation of $\mathrm{Crhr} 1$ expression in the anterior pituitary, resulting in prolonged HPA axis activation in restrained LBW offspring.
\end{abstract}

\section{Key Words}

- low birth weight

- psychopathology

- stress

- HPA axis

- CRF receptor

- miRNA

\section{Introduction}

Low birth weight (LBW) is reportedly related to an increased prevalence of common cardiovascular and metabolic disorders later in life, including hypertension, coronary heart disease, type 2 diabetes, and hyperlipidemia (Levitt et al. 2000, Reynolds et al. 2001, Davies et al. 2004, Irving et al. 2004). Furthermore, accumulating evidence indicates that LBW is associated with psychopathologies such as depression, schizophrenia, and autism (Wahlbeck et al. 2001, Indredavik et al. 2004, Raikkonen et al. 2008, Schendel \& Bhasin 2008). These disorders are associated with abnormalities of the hypothalamicpituitary-adrenal (HPA) axis such as disturbed circadian 
rhythm, impaired cortisol suppression by dexamethasone (Holsboer-Trachsler et al. 1987, Hoshino et al. 1987, Vreeburg et al. 2009, Hempel et al. 2010), and abnormal adrenocorticotropin (ACTH) and cortisol responses to corticotropin-releasing factor (CRF) or stress (Young et al. 2000, Ehnvall et al. 2004, Corbett et al. 2006). Recent animal studies have indicated that maternal malnutritioninduced impairment of fetal programing of the HPA axis function is associated with adult-onset dysregulation of the axis (Chadio et al. 2007, Rumball et al. 2008, Buhl et al. 2010). Dysregulation of the HPA axis function is the most common and consistently reported abnormality in depression (Reus et al. 1985). In human studies, LBW has been shown to be related to alternations in HPA axis function in adult life, such as elevated basal morning cortisol levels, enhanced cortisol responses to $\mathrm{ACTH}_{(1-24)}$ or CRF challenge test, and increased urinary cortisol metabolite excretion (Levitt et al. 2000, Ward et al. 2004, de Rooij et al. 2006). In addition to maternal malnutrition, prenatally stressed animals show LBW, enhanced basal levels of corticosterone and prolonged responses of the HPA axis to stress, impaired feedback regulation by glucocorticoids, and fewer glucocorticoid receptors (GRs) in the hippocampus (Clarke et al. 1994, Koehl et al. 1999, Bhatnagar et al. 2005, Viltart et al. 2006, Owen \& Matthews 2007, Brunton \& Russell 2010). Stress activates the synthesis and release of hypothalamic CRF, pituitary ACTH, and adrenal glucocorticoids. Corticotropes in the anterior pituitary are key elements in the regulatory mechanisms of the HPA axis: glucocorticoids downregulate not only Crf (Crh) mRNA expression at the hypothalamus, but also CRF type 1 receptor (Crf-r1, Crhr1) and proopiomelanocortin (Pomc) mRNA expression and ACTH secretion in the anterior pituitary (Birnberg et al. 1983, Kovacs \& Mezey 1987, Zhou et al. 1996, Ochedalski et al. 1998). To our knowledge, no reports have addressed the pathophysiological role of the anterior pituitary in dysregulation of the negative feedback system of the HPA axis under stress in LBW offspring. Therefore, in this study, we used rats delivered from malnourished dams to explore the role of the anterior pituitary in the mechanism underlying the abnormal HPA axis response to stress, as such abnormal responses may be associated with psychopathologies such as depression, schizophrenia, and autism in humans with LBW.

In this study, LBW offspring, who had been delivered from calorie-restricted (60\% of that of control) dams, showed delayed restoration of plasma ACTH and corticosterone to basal levels and impaired Crhr1 downregulation in the anterior pituitary during restraint. We then examined the expression of miR449a, which we have previously demonstrated to be involved in Crhr1 downregulation (Nemoto et al. 2013), in the anterior pituitary of restrained LBW or normal-birth-weight (NBW) rats. As microRNAs (miRNAs) have been recently shown to be present in exosomes released from cells and those exosomal miRNAs are stable in the blood or extracellular fluids (Hunter et al. 2008, Turchinovich et al. 2011), we attempted to detect exosomal miR449a in blood and culture medium of rat anterior pituitary cells. Finally, we examined the expression of Gas5 non-coding RNA (ncRNA), which inhibits GR binding to glucocorticoid-responsive elements in DNA and blocks glucocorticoid-induced changes in gene expression (Kino et al. 2010), in order to explore its role in the regulation of miR449a expression.

\section{Materials and methods}

\section{Animals}

Wistar rats were maintained at $23 \pm 2{ }^{\circ} \mathrm{C}$ under a $12 \mathrm{~h}$ light: $12 \mathrm{~h}$ darkness cycle (lights on at $0800 \mathrm{~h}$ and off at $2000 \mathrm{~h}$ ) and were allowed to access laboratory chow and distilled water ad libitum. All experimental procedures were approved by the laboratory animals ethics review committee of Nippon Medical School.

Twenty proestrus female rats (age, 9 weeks) were mated with normal male rats. Dams were housed individually with free access to water and were divided into two groups; food intake of food-restricted (FR) dams was restricted to $60 \%$ of the control group, while control dams freely accessed food during the entire gestational period. Both dam groups delivered at gestational day 22; average numbers of offspring from control and FR dams were 15.0 (range 12-20) and 13.8 (range 12-17), and male to female ratios were 5:6 and 6:5 respectively. Mean body weights at birth of male offspring delivered from control dams (NBW) and offspring delivered from FR dams (LBW) were $5963 \pm 5 \mathrm{mg}(n=25)$ and $4618 \pm 63 \mathrm{mg}$ $(n=65)(P<0.001)$ respectively. After parturition, FR dams were allowed to access food ad libitum. Both offspring groups were weaned at 21 days of age and were allowed to access laboratory chow and water ad libitum. Only male offspring were used in experiments, as female rats showed menstrual cycle-dependent responses to the stress (Iwasaki-Sekino et al. 2009). Each experimental group consisted of offspring from at least three litters. Mean body weights of NBW and LBW males used in this study at day 42 were $202.3 \pm 3.5$ and $193.2 \pm 2.9 \mathrm{~g}(P=0.145$, un-paired $t$-test), $n=60$ respectively.

Published by Bioscientifica Ltd 


\section{Diurnal change analysis}

Six-week-old NBW and LBW $(n=24)$ offspring were killed by decapitation at $0200,0800,1400$, and $2000 \mathrm{~h}$. Trunk blood and their anterior pituitaries were collected.

\section{Restraint stress exposure}

Six-week-old rats were wrapped in a flexible wire mesh $(12 \times 12 \mathrm{~mm})$ and kept for $30,60,90$, or 120 min between 0900 and $1200 \mathrm{~h}$ in an isolated room. Rats were killed in the adjacent room immediately after restraint and their trunk blood and anterior pituitaries were collected. Non-stressed control rats were housed in a separate room and were killed in the same way and subjected to identical processing.

\section{Primary culture of anterior pituitary cells}

Thirty normal rats (age, 6 weeks) were killed by decapitation and their anterior pituitaries were removed under sterile conditions. Anterior pituitary cells were cultured as described previously (Nemoto et al. 2009, 2010). Cells were allowed to attach to the plating surfaces at $37^{\circ} \mathrm{C}$ in a humidified 5\% $\mathrm{CO}_{2}-95 \%$ air incubator for 4 days. Cells were then treated with dexamethasone at concentrations of 10 and $100 \mathrm{ng} / \mathrm{ml}$ for $1 \mathrm{~h}$.

\section{Exosome purification}

Serum samples or culture media $(250 \mu \mathrm{l})$ were mixed with ExoQuick exosome precipitation solution (System Bioscience, Inc., Mountain View, CA, USA). Purified exosome samples were resuspended in ultrapure water.

\section{RNA extraction and real-time RT-PCR analysis}

Total RNA was extracted from cultured pituitary cells and rat pituitaries using RNAiso Plus (Takara, Shiga, Japan).
The absorbance of each sample at wavelengths of 260 and $280 \mathrm{~nm}$ was assayed, and RNA purity was estimated to be the $260 \mathrm{~nm} / 280 \mathrm{~nm}$ ratio (the $260 \mathrm{~nm} / 280 \mathrm{~nm}$ ratio of all samples used in this study was higher than 1.7). For miRNA expression analysis, first-strand cDNA was synthesized at $37^{\circ} \mathrm{C}$ for $1 \mathrm{~h}$ using $1 \mu \mathrm{g}$ of denatured total RNA and then terminated at $85^{\circ} \mathrm{C}$ for 5 min using Mir-X miRNA First-Strand Synthesis and SYBR qRT-PCR kit (Clontech Laboratories, Inc.). For mRNA and Gas5 ncRNA expression analyses, first-strand cDNA was generated using $0.5 \mu \mathrm{g}$ of denatured total RNA; the reaction mixture was incubated at $37^{\circ} \mathrm{C}$ for $15 \mathrm{~min}, 84^{\circ} \mathrm{C}$ for $5 \mathrm{~s}$, and $4{ }^{\circ} \mathrm{C}$ for 5 min using a PrimeScript RT reagent kit with gDNA Eraser (Takara). PCR was performed by denaturation at $94{ }^{\circ} \mathrm{C}$ for $5 \mathrm{~s}$ and annealing extension at $60{ }^{\circ} \mathrm{C}$ for $30 \mathrm{~s}$ for 40 cycles, using SYBR premix Ex Taq (Takara) and specific primer set for rat Pomc, Gr, Crhr1, Gas5, or Gapdh (Table 1). To normalize each sample for RNA content, GAPDH, a house-keeping gene, and U6 small nuclear RNA (Clontech Laboratories, Inc.) were used for mRNA, ncRNA, and miRNA expression analyses respectively. Diluted normal rat pituitary cDNA and the second derivative method were used as the standard and for calculating $C t$ values respectively (Nolan et al. 2006).

\section{Western blotting of Crhr1}

The anterior pituitary tissues were lysed with TNE buffer (10 mM Tris- $\mathrm{HCl}, \mathrm{pH} 7.8,1 \% \mathrm{NP}-40,150 \mathrm{mM} \mathrm{NaCl}$, and $1 \mathrm{mM}$ EDTA) containing the Complete proteinase inhibitor cocktail (Roche Diagnostics). After centrifugation to remove debris, protein concentrations in the supernatant were measured. Protein extracts $(20 \mu \mathrm{g})$ were mixed with $3 \times$ SDS sample buffer $(200 \mathrm{mM}$ Tris- $\mathrm{HCl}, \mathrm{pH}$ $6.8,30 \%$ glycerol, $6 \%$ SDS, $0.03 \%$ bromophenol blue, and $3 \% \beta$-mercaptoethanol) and boiled for $5 \mathrm{~min}$. They were then separated by SDS-PAGE and transferred onto

Table 1 Primer sequences of the studied genes

\begin{tabular}{|c|c|}
\hline Genes & Primers \\
\hline Pomc & $\begin{array}{l}\text { CCTCCATAGACGTGTGGAGCTG } \\
\text { AAGGGCTGTTCATCTCCGTTG }\end{array}$ \\
\hline$G r(N r 3 c 1)$ & $\begin{array}{l}\text { CATGTTAGGTGGGCGTCAAGTG } \\
\text { GGTCATTTGGTCATCCAGGTGTAAG }\end{array}$ \\
\hline Crhr1 (Crhr1) & $\begin{array}{l}\text { TCGGCTTTCATCCTACGCAAC } \\
\text { AATTGTAGGCGGCTGTCACCA }\end{array}$ \\
\hline Gas5 & $\begin{array}{l}\text { AACTGAAGGCATGGCAAGCTC } \\
\text { CACTGCACTGTCCACTTGTCAGA }\end{array}$ \\
\hline Gapdh & $\begin{array}{l}\text { GGCACAGTCAAGGCTGAGAATG } \\
\text { ATGGTGGTGAAGACGCCAGTA }\end{array}$ \\
\hline
\end{tabular}

\begin{tabular}{ccc}
\hline Length $(\mathrm{bp})$ & & $\begin{array}{c}\text { Accession number } \\
\text { (GenBank) }\end{array}$ \\
\cline { 1 - 1 } & & NM_139326 \\
$91(1756-1846)$ & & NM_012576 \\
$112(478-589)$ & & NM_030999 \\
$81(244-324)$ & & NR_002704 \\
$143(242-384)$ & & NM_017008
\end{tabular}


PVDF membranes. The membranes were blocked with $10 \%$ nonfat dried milk and primed with an anti-Crhr1 antibody (C-20) (1:500) (Nemoto et al. 2013). Membranes were washed and incubated with HRP-conjugated antigoat IgG (Jackson Immuno Research Laboratory, West Grove, PA, USA). Immunoreactivity was detected and quantified with ChemiDoc XRS (Bio-Rad Laboratories, Inc.) using SuperSignal West Dura Extended Duration Substrate (Thermo Scientific, Rockford, IL, USA). After detecting Crhr1 signals, antibodies were stripped from membranes by incubation in Restore PLUS western blot stripping buffer (Thermo Scientific), followed by re-priming with anti- $\beta$-actin MAB (GeneScript, Piscataway, NJ, USA) and HRP-conjugated anti-mouse-IgG (Jackson Immuno Research Laboratory). Signals were then detected and quantified to normalize for differences in blotting efficiency and protein loading. Expression levels were calculated as follows: (intensity of $60-\mathrm{kDa}$ band +the intensity of $40-\mathrm{kDa}$ band)/intensity of $\beta$-actin. Data are given as a percentage of non-stressed or control values.

\section{Statistical analysis}

Statistical analyses were performed using one-way ANOVA followed by Tukey's post hoc test or using two-way ANOVA with the Bonferroni multiple comparisons post test using the Prism 5.0 software (GraphPad
Software, Inc., La Jolla, CA, USA). All results were expressed as mean \pm s.E.M. Statistical significance was set at the level of $P<0.05$.

\section{Results}

\section{LBW offspring showed impaired feedback regulation of HPA axis}

There were no significant differences in basal ACTH or corticosterone levels between NBW and LBW offspring when the restraint stress session started at $0900 \mathrm{~h}$. Restraint stress significantly increased plasma ACTH and corticosterone levels at $30(n=6, P<0.001$ for both ACTH and corticosterone, non-stressed vs $30 \mathrm{~min}$ ) and $60 \min (n=6, P<0.001$ for both ACTH and corticosterone, non-stressed vs $60 \mathrm{~min}$ ), and both hormones were significantly lower at $90(n=6, P<0.001$, for both ACTH and corticosterone, $60 \mathrm{~min}$ vs $90 \mathrm{~min})$ and $120 \mathrm{~min}(n=6$, $P<0.001$, for both ACTH and corticosterone, 60 min vs 90 min) in NBW (Fig. 1A and B) offspring. Restraint stress exposure also significantly increased plasma ACTH and corticosterone levels in LBW offspring $(n=6, P<0.001$, for both ACTH and corticosterone, non-stressed vs 30 and $60 \mathrm{~min})$, and they remained elevated at significantly higher levels than those of NBW offspring at $90 \mathrm{~min}$ $(n=6, P<0.001$ for both ACTH and corticosterone, NBW vs LBW offspring) and $120 \mathrm{~min}(n=6, P<0.0001$ for ACTH, NBW vs LBW) (Fig. 1A and B).
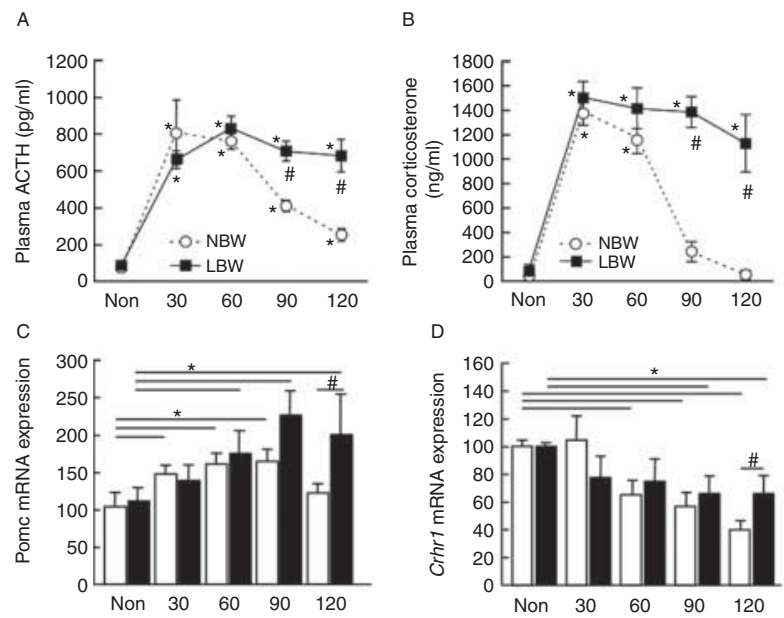

Figure 1

Impaired HPA axis regulation in restrained LBW offspring. NBW and LBW offspring were restrained for 30,60, 90, or $120 \mathrm{~min}$. Their plasma ACTH (A) and corticosterone (B) concentrations, and Pomc (C) and Crhr1 (D) mRNA expression in the anterior pituitary were assayed. Crhr1 protein expression in the anterior pituitary was assayed (E for typical image, F and $G$ for three
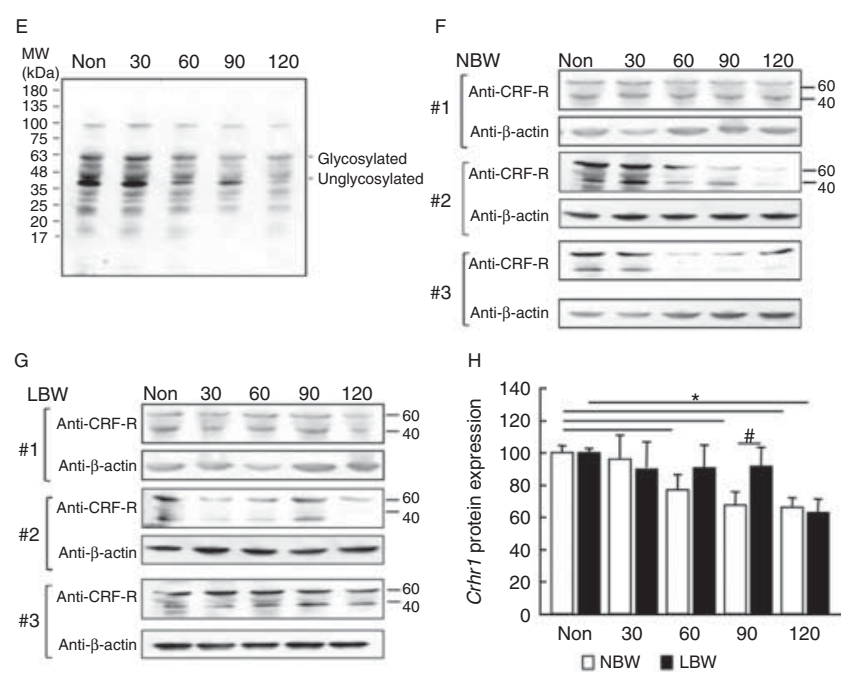

independent blot images for NBW and LBW offspring respectively, and $\mathrm{H}$ for quantification results). mRNA and protein expression levels are shown as $\%$ of non-stressed (non) NBW offspring. $n=6$. *Indicates significance vs non using Turkey's post hoc analysis,

\#indicates significance vs NBW using Turkey's post hoc analysis. 
Restraint stress significantly increased Pomc mRNA expression in the anterior pituitary at 30,60, and $90 \mathrm{~min}$ in NBW offspring $(n=6, P<0.05, P<0.01$, and $P<0.05$ for non-stressed vs 30, 60, and 90 min respectively) and at 60 and 90 min LBW offspring $(n=6, P<0.05$, and $P<0.01$ for non-stressed vs 60 and 90 min respectively), and Pomc mRNA expression levels were restored to basal level at 120 min in NBW offspring while those of LBW offspring remained significantly high even at $120 \mathrm{~min}(n=6$, $P<0.01$, NBW vs LBW) (Fig. 1C). Restraint stress significantly decreased Crhr1 mRNA expression in the anterior pituitary at 60,90, and 120 min in NBW offspring $(n=6$, $P<0.01, P<0.001$, and $P<0.0001$ for non-stressed vs 60, 90, and $120 \mathrm{~min}$ respectively), but Crhr1 mRNA expression at $120 \mathrm{~min}$ was significantly higher in LBW offspring than in NBW offspring ( $n=6, P<0.05$, NBW vs LBW) (Fig. 1D).

We detected Crhr1 protein expression using anti-CRF receptor antibodies as described previously (Nemoto et al.
2013; Fig. 1E, F, and G). Restraint stress significantly decreased Crhr1 protein at 60, 90, and 120 min in NBW offspring ( $n=6, P<0.001, P<0.0001$, and $P<0.0001$ for non-stressed vs 60,90 , and $120 \mathrm{~min}$ respectively), and significantly decreased Crhr1 protein only at $120 \mathrm{~min}$ in LBW offspring ( $n=6, P<0.0001$ for non-stress vs $120 \mathrm{~min}$ ) (Fig. 1H). The Crhr1 protein levels at $90 \mathrm{~min}$ were significantly higher in LBW offspring than in NBW offspring ( $n=6, P<0.01$, NBW vs LBW) (Fig. $1 \mathrm{H}$ ).

\section{Restraint-induced miR449a expression is impaired in LBW rats}

Restraint stress significantly increased miR449a expression in the anterior pituitary and serum exosome in NBW offspring ( $n=6, P<0.05$ for pituitary expression and serum exosome content, non-stressed vs $90 \mathrm{~min}$ ) but not in LBW offspring ( $n=6, P<0.05$ for pituitary expression and serum exosome content, NBW vs LBW) (Fig. 2A and B).
A

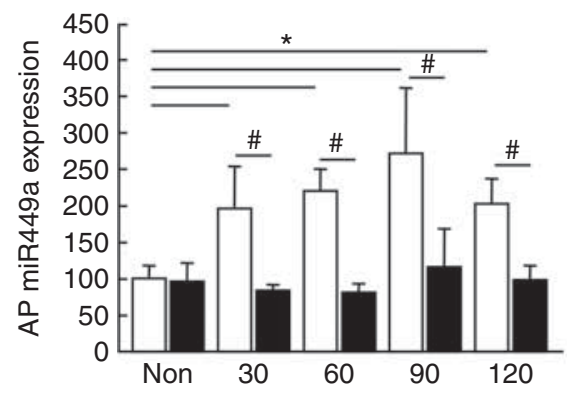

B

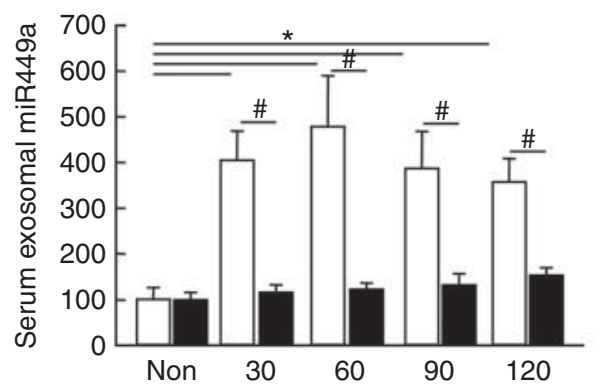

NBW

C

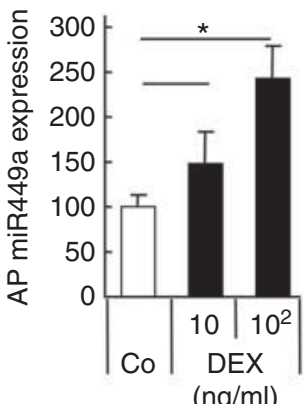

$\mathrm{F}$

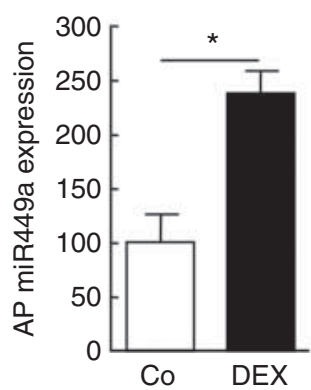

D

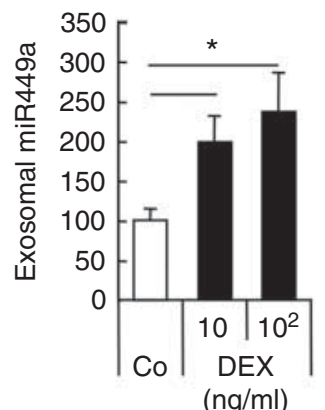

G

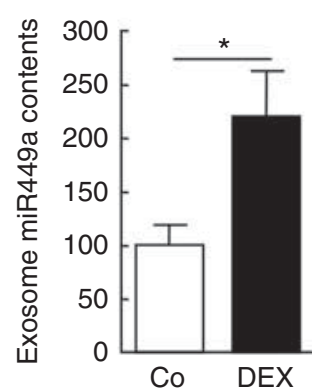

$E$

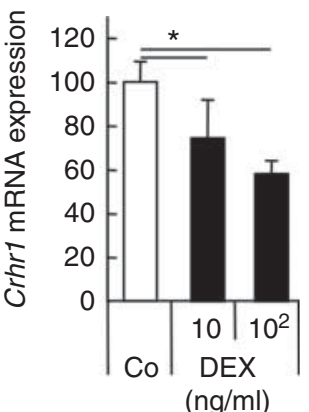

$\mathrm{H}$

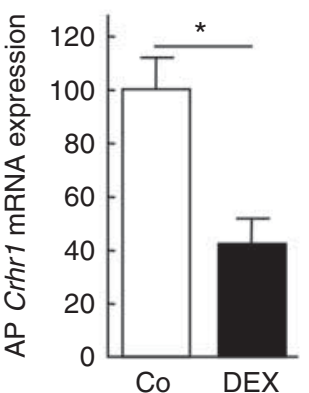

Figure 2

miR449a is expressed and secreted by anterior pituitary cells and stress- and dexamethasone-induced increase in expression of miR449a is abolished in LBW offspring. NBW and LBW offspring were restrained for 30,60,90, or $120 \mathrm{~min}$, and miR449a in the anterior pituitary (A) and serum exosomes (B) were assayed. Expression of miR449a and exosomal miR449a contents from culture media of dexamethasone-treated anterior pituitary cells ( $C$ for expression and D for exosomal contents) and expression of Crhr1 mRNA (E) in cells were measured. Dexamethasone $(30 \mu \mathrm{g} / \mathrm{kg}$ body weight) was intraperitoneally injected into naive rats $(n=8)$, and miR449a expression in the anterior pituitary (F), serum exosome miR449a contents (G), and Crhr1 mRNA expression $(\mathrm{H})$ in the anterior pituitary were assayed after $120 \mathrm{~min}$ of injection. *Indicates significance vs control (co) or vs non-stressed group (non) using Turkey's post hoc analysis, "indicates significance vs NBW using Turkey's post hoc analysis. 
Expression of miR449a and contents of exosomal miR449a from culture media of anterior pituitary cells were increased with dexamethasone at a concentration of $100 \mathrm{ng}(n=6, P<0.01$ for expression and $P<0.05$ for exosome contents, control vs $100 \mathrm{ng} / \mathrm{ml}$ ), which significantly suppressed Crhr1 mRNA expression in the anterior pituitary cells ( $n=6, P<0.05$, control vs $100 \mathrm{ng} / \mathrm{ml}$ ) (Fig. 2C, D, and E). Administration of dexamethasone (i.p., $30 \mu \mathrm{g} / \mathrm{kg}$ body weight (BW)) to naive rats significantly increased miR449a expression in the anterior pituitary and serum exosome content $(n=6, P<0.001$ for anterior pituitary expression and $P<0.05$ for serum exosome content, saline vs $30 \mu \mathrm{g} / \mathrm{kg} \mathrm{BW}$ ), which significantly suppressed Crhr1 mRNA expression in the anterior pituitary ( $n=8, P<0.001$, saline vs $30 \mu \mathrm{g} / \mathrm{kg} \mathrm{BW}$ ) (Fig. $2 \mathrm{~F}$, $\mathrm{G}$, and I).

\section{Diurnal changes of plasma corticosterone and miR449a expression in the anterior pituitary}

Plasma corticosterone concentrations were highest at $2000 \mathrm{~h}$ and lowest at $0200 \mathrm{~h}$ in NBW offspring $(n=6$, $P<0.001,2000 \mathrm{~h}$ vs $0200 \mathrm{~h}$ ), and were highest at $2000 \mathrm{~h}$ and lowest at $0800 \mathrm{~h}$ in LBW offspring ( $n=6, P<0.001$, $2000 \mathrm{~h}$ vs $0800 \mathrm{~h}$ ) (Fig. 3A). The plasma corticosterone concentrations at 2000 and $0200 \mathrm{~h}$ were significantly higher in LBW offspring than in NBW offspring $(n=6$, $P<0.05$ fat $2000 \mathrm{~h}$ and $P<0.001$ at $0200 \mathrm{~h}, \mathrm{NBW}$ vs LBW) (Fig. 3A). Although there were no significant changes in the anterior pituitary miR449a expression levels at 0800, 1400, 2000, and $0200 \mathrm{~h}$ in either NBW or LBW offspring, the expression levels at 2000 and $0200 \mathrm{~h}$ were significantly lower in LBW offspring than in NBW offspring $(n=6$, $P<0.001$ at $2000 \mathrm{~h}$ and $P<0.05$ at $0200 \mathrm{~h}, \mathrm{NBW}$ vs LBW) (Fig. 3B).

\section{GAS5 expression in anterior pituitary is elevated in LBW offspring}

Restraint stress did not induce any significant changes in GAS5 expression in the anterior pituitary in either NBW or LBW offspring; however, GAS5 expression levels in the anterior pituitary were significantly higher in LBW offspring than in NBW offspring before and during restraint ( $n=6, P<0.001$ for non-stressed and $P<0.05$ at 30, 60, 90, and 120 min, NBW vs LBW) (Fig. 4A).

Restraint stress significantly increased anterior pituitary $\mathrm{Gr}$ mRNA expression at $60 \mathrm{~min}$ in NBW offspring ( $n=6, P<0.05$, non-stress vs $60 \mathrm{~min}$ ), and at 60,90 , and 120 min in LBW offspring $(n=6, P<0.05$ at 60,90 , and
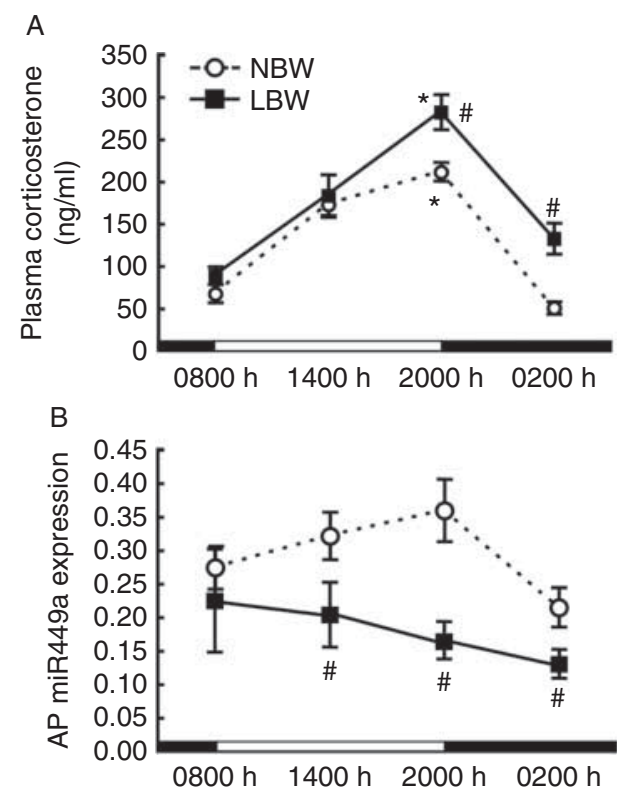

Figure 3

Diurnal change in corticosterone and miR449a expression in the anterior pituitary. NBW and LBW offspring were killed at 0800, 1400, 2000, and $0200 \mathrm{~h}$. Plasma corticosterone (A) and miR449a expression in the anterior pituitary (B) were assayed. $n=6$. *Indicates significance vs $0800 \mathrm{~h}$ using Turkey's post hoc analysis, "indicates significance vs NBW using Turkey's post hoc analysis.

120 min, non-stress vs restraint). Although the restraintinduced increase in $\mathrm{Gr}$ mRNA expression was restored to basal levels at 90 and $120 \mathrm{~min}$ in NBW offspring, it remained at significantly high levels at 90 and $120 \mathrm{~min}$ in LBW offspring $(n=6, P<0.05$ at $90 \mathrm{~min}$ and $P<0.01$ at 120 min, NBW vs LBW) (Fig. 4B).

\section{Discussion}

This study demonstrated impaired restoration of ACTH and corticosterone secretion and Pomc and Gr mRNA expression during restraint in the anterior pituitary of LBW offspring in accordance with previous reports (Buhl et al. 2007, 2010). Although several research groups have attempted to elucidate the mechanism underlying the dysfunction of the HPA axis in LBW offspring by analyzing GRs in the hypothalamus, hippocampus, and amygdala (Lesage et al. 2002, Sebaai et al. 2002, 2004), the details of this mechanism remain unclear. In this study, we focused on the anterior pituitary, where CRF acts to stimulate POMC expression and ACTH secretion through Crhr1 and glucocorticoids act to modulate ACTH secretion through GRs; our results indicated that mRNA and protein levels of Crhr1 in the anterior pituitary were significantly

Published by Bioscientifica Ltd 

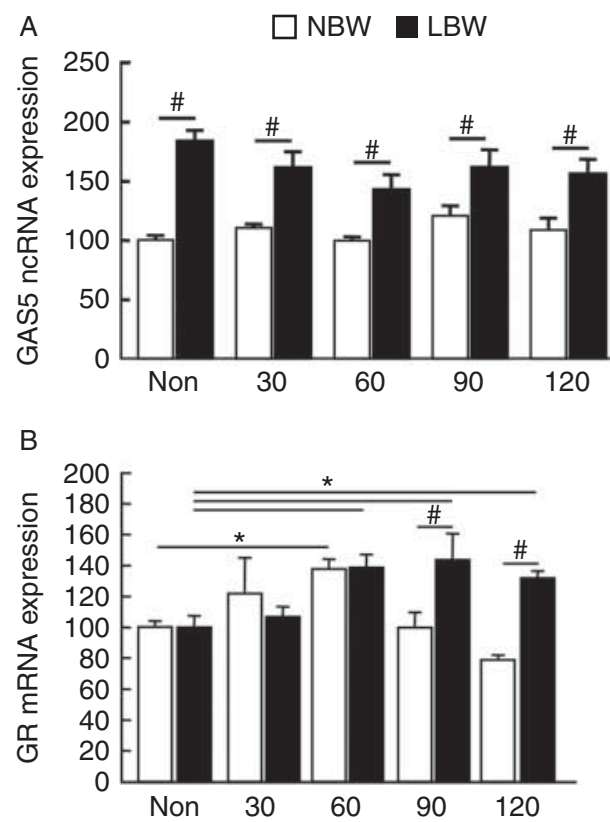

\section{Figure 4}

GAS5 expression and GR expression in the anterior pituitary under restraint. NBW and LBW offspring were restrained for $30,60,90$, or $120 \mathrm{~min}$, and their GAS5 (A) and GR mRNA (B) expressions in the anterior pituitary of LBW and NBW offspring were assayed. $n=6$. "Indicates significance vs NBW using Turkey's post hoc analysis, * indicates significance vs non-stressed group (non) using Turkey's post hoc analysis.

reduced by restraint in both NBW and LBW offspring, but Crhr1 mRNA levels at 120 min and Crhr1 protein levels at $90 \mathrm{~min}$ were significantly higher in restrained LBW offspring than in restrained NBW offspring. These results therefore indicate that impaired downregulation of Crhr1 is involved in the prolonged Pomc mRNA expression and ACTH secretion in the anterior pituitary of LBW offspring.

The expression of miR449a in the anterior pituitary was increased by restraint in NBW offspring but not in LBW offspring. We have previously demonstrated that overexpression of miR449a suppressed mRNA and protein expression of Crhr1, and knockdown of miR449a blocked dexamethasone-induced suppression of Crhr1 expression (Nemoto et al. 2013), indicating that miR449a suppresses Crhr1 expression. Results of a previous in vitro study had also indicated that the expression of miR449a was positively regulated by glucocorticoids, but not by CRF. ADX completely blocked restraint-induced increases in miR449a expression. Furthermore, we had previously demonstrated that expression levels of Crhr1 mRNA and protein were significantly higher at several points during restraint stress exposure in ADX rats than in sham rats, although the expression of Crhr1 mRNA and protein were significantly reduced during immobilization (Nemoto et al. 2013). In this study, we demonstrated that both miR449a expression in the anterior pituitary and plasma corticosterone levels were highest at $2000 \mathrm{~h}$ and lowest at $0200 \mathrm{~h}$ in NBW offspring. Taken together, our findings indicate that corticosterone-induced miR449a expression in the anterior pituitary was defected and that inhibition of miR449a consequently impairs the downregulation of Crhr1 expression during restraint in LBW offspring.

We then examined pituitary GAS5 expression because GAS5 inhibits GR binding to glucocorticoid-responsive elements in DNA and blocks glucocorticoid-induced changes in gene expression (Kino et al. 2010). We actually found that the expression of GAS5 was significantly higher in LBW offspring than in NBW offspring in this study. Moreover, we found that both miR449a expression in the anterior pituitary and plasma corticosterone levels have diurnal rhythm in NBW offspring, while rhythm of plasma corticosterone levels were impaired in LBW offspring. Therefore, it seems likely that overexpression of GAS5 blocks corticosterone action, thereby causing suppression of miR449a expression in LBW offspring despite prolonged elevation of $G r$ mRNA expression in the anterior pituitary. The elevated expression of GAS5 may be an obstacle to GR autoregulation in the anterior pituitary of LBW offspring during restraint. Although GAS5 expression is reportedly increased in the hippocampus by psychogenic stress in mice (Meier et al. 2010), there were no changes in GAS5 expression in the pituitary during immobilization in either NBW or LBW offspring in this study. Moreover, we were unable to detect any changes in GAS5 expression in dexamethasone-treated anterior pituitary cells in vitro (data not shown), thus suggesting that GAS5 expression in the anterior pituitary is regulated in a glucocorticoidindependent manner. However, glucocorticoids may be involved in the regulation of GAS5 expression in the fetal pituitary as hypercorticosteronemia is present in FR dams, and hypercorticosteronemia appears to modulate the programing of the HPA axis in fetuses (Catalani et al. 2002).

In this study, we detected miR449a expression in both the anterior pituitary and exosomes in the culture medium of anterior pituitary cells and serum. Serum exosomal miR449a increased in parallel with miR449a mRNA expression in the anterior pituitary of restrained rats. As miR449a is expressed in the brain and various peripheral tissues (Linsen et al. 2010), the origin of serum exosomal miR449a is unclear. However, the results of this study indicate that the anterior pituitary is one of the original sites for miR449a-containing exosomes in peripheral circulation, as exosomal miR449a in the

Published by Bioscientifica Ltd. 
culture medium of anterior pituitary cells was increased by dexamethasone. As exosomes carry proteins, RNAs, and miRNAs, mediate cell-to-cell signaling, and are released into extracellular fluids in a paracrine manner (Sahoo et al. 2011), miR449a-containing exosomes may have a paracrine role in the anterior pituitary. Furthermore, because restraint significantly increased serum exosomal miR449a in NBW offspring but not in LBW offspring and the sequences of miR449a and its binding region of CRFR1 3'UTR have $100 \%$ homologies between human and rats, quantification of serum exosomal miR449a would be a useful tool for evaluation of dysregulation of the HPA axis in stress in humans.

This study demonstrated that impairment of miR449a expression, which is probably caused by enhanced expression of GAS5, induces prolonged elevation of plasma corticosterone levels via delayed lowering of Crhr1 expression in the anterior pituitary of LBW offspring delivered from malnourished dams.

\section{Declaration of interest}

The authors declare that there is no conflict of interest that could be perceived as prejudicing the impartiality of the research reported.

\section{Funding}

This study was supported in part by Research on Measures for Intractable Diseases, Health and Labor Sciences Research Grants from the Ministry of Health, Labor and Welfare, and Ministry of Education, Culture, Sports, Science and Technology (MEXT)-supported program for the Strategic Research Foundation at Private Universities, 2008-2012, and JSPS KAKENHI grant number 23791238.

\section{References}

Bhatnagar S, Lee TM \& Vining C 2005 Prenatal stress differentially affects habituation of corticosterone responses to repeated stress in adult male and female rats. Hormones and Behavior 47 430-438. (doi:10.1016/ j.yhbeh.2004.11.019)

Birnberg NC, Lissitzky JC, Hinman M \& Herbert E 1983 Glucocorticoids regulate proopiomelanocortin gene expression in vivo at the levels of transcription and secretion. PNAS 80 6982-6986. (doi:10.1073/pnas. 80.22.6982)

Brunton PJ \& Russell JA 2010 Prenatal social stress in the rat programmes neuroendocrine and behavioural responses to stress in the adult offspring: sex-specific effects. Journal of Neuroendocrinology 22 258-271. (doi:10.1111/j.1365-2826.2010.01969.x)

Buhl ES, Neschen S, Yonemitsu S, Rossbacher J, Zhang D, Morino K, Flyvbjerg A, Perret P, Samuel V, Kim J et al. 2007 Increased hypothalamic-pituitary-adrenal axis activity and hepatic insulin resistance in low-birth-weight rats. American Journal of Physiology. Endocrinology and Metabolism 293 E1451-E1458. (doi:10.1152/ajpendo. 00356.2007)

Buhl ES, Jensen TK, Jessen N, Elfving B, Buhl CS, Kristiansen SB, Pold R, Solskov L, Schmitz O, Wegener G et al. 2010 Treatment with an SSRI antidepressant restores hippocampo-hypothalamic corticosteroid feedback and reverses insulin resistance in low-birth-weight rats. American Journal of Physiology. Endocrinology and Metabolism 298 E920-E929. (doi:10.1152/ajpendo.00606.2009)

Catalani A, Casolini P, Cigliana G, Scaccianoce S, Consoli C, Cinque C, Zuena AR \& Angelucci L 2002 Maternal corticosterone influences behavior, stress response and corticosteroid receptors in the female rat. Pharmacology, Biochemistry, and Behavior 73 105-114. (doi:10.1016/ S0091-3057(02)00755-4)

Chadio SE, Kotsampasi B, Papadomichelakis G, Deligeorgis S, Kalogiannis D, Menegatos I \& Zervas G 2007 Impact of maternal undernutrition on the hypothalamic-pituitary-adrenal axis responsiveness in sheep at different ages postnatal. Journal of Endocrinology 192 495-503. (doi:10.1677/JOE-06-0172)

Clarke AS, Wittwer DJ, Abbott DH \& Schneider ML 1994 Long-term effects of prenatal stress on HPA axis activity in juvenile rhesus monkeys. Developmental Psychobiology 27 257-269. (doi:10.1002/dev.420270502)

Corbett BA, Mendoza S, Abdullah M, Wegelin JA \& Levine S 2006 Cortisol circadian rhythms and response to stress in children with autism. Psychoneuroendocrinology 31 59-68. (doi:10.1016/j.psyneuen. 2005.05.011)

Davies AA, Smith GD, Ben-Shlomo Y \& Litchfield P 2004 Low birth weight is associated with higher adult total cholesterol concentration in men: findings from an occupational cohort of 25,843 employees. Circulation 110 1258-1262. (doi:10.1161/01.CIR.0000140980.61294.4D)

Ehnvall A, Sjogren M, Zachrisson OC \& Agren H 2004 HPA axis activation determined by the CRH challenge test in patients with few versus multiple episodes of treatment-refractory depression. European Archives of Psychiatry and Clinical Neuroscience 254 349-355. (doi:10.1007/ s00406-004-0512-3)

Hempel RJ, Tulen JH, van Beveren NJ, Roder CH, de Jong FH \& Hengeveld MW 2010 Diurnal cortisol patterns of young male patients with schizophrenia. Psychiatry and Clinical Neurosciences 64 548-554. (doi:10.1111/j.1440-1819.2010.02121.x)

Holsboer-Trachsler E, Buol C, Wiedemann K \& Holsboer F 1987 Dexamethasone suppression test in severe schizophrenic illness: effects of plasma dexamethasone and caffeine levels. Acta Psychiatrica Scandinavica 75 608-613. (doi:10.1111/j.1600-0447.1987.tb02844.x)

Hoshino Y, Yokoyama F, Watanabe M, Murata S, Kaneko M \& Kumashiro H 1987 The diurnal variation and response to dexamethasone suppression test of saliva cortisol level in autistic children. Psychiatry and Clinical Neurosciences 41 227-235. (doi:10.1111/j.1440-1819.1987. tb00406.x)

Hunter MP, Ismail N, Zhang X, Aguda BD, Lee EJ, Yu L, Xiao T, Schafer J, Lee ML, Schmittgen TD et al. 2008 Detection of microRNA expression in human peripheral blood microvesicles. PLOS ONE 3 e3694. (doi:10.1371/journal.pone.0003694)

Indredavik MS, Vik T, Heyerdahl S, Kulseng S, Fayers P \& Brubakk AM 2004 Psychiatric symptoms and disorders in adolescents with low birth weight. Archives of Disease in Childhood 89 F445-F450. (doi:10.1136/ adc.2003.038943)

Irving RJ, Shore AC, Belton NR, Elton RA, Webb DJ \& Walker BR 2004 Low birth weight predicts higher blood pressure but not dermal capillary density in two populations. Hypertension 43 610-613. (doi:10.1161/ 01.HYP.0000116029.85706.5f)

Iwasaki-Sekino A, Mano-Otagiri A, Ohata H, Yamauchi N \& Shibasaki T 2009 Gender differences in corticotropin and corticosterone secretion and corticotropin-releasing factor mRNA expression in the paraventricular nucleus of the hypothalamus and the central nucleus of the amygdala in response to footshock stress or psychological stress in rats. Psychoneuroendocrinology 34 226-237. (doi:10.1016/j.psyneuen. 2008.09.003)

Kino T, Hurt DE, Ichijo T, Nader N \& Chrousos GP 2010 Noncoding RNA gas5 is a growth arrest- and starvation-associated repressor of the glucocorticoid receptor. Science Signaling 3 ra8. (doi:10.1126/scisignal. 2000568) 
Koehl M, Darnaudery M, Dulluc J, Van Reeth O, Le Moal M \& Maccari S 1999 Prenatal stress alters circadian activity of hypothalamo-pituitaryadrenal axis and hippocampal corticosteroid receptors in adult rats of both gender. Journal of Neurobiology 40 302-315. (doi:10.1002/ (SICI)1097-4695(19990905)40:3 < 302::AID-NEU3 > 3.0.CO;2-7)

Kovacs KJ \& Mezey E 1987 Dexamethasone inhibits corticotropin-releasing factor gene expression in the rat paraventricular nucleus. Neuroendocrinology 46 365-368. (doi:10.1159/000124846)

Lesage J, Dufourny L, Laborie C, Bernet F, Blondeau B, Avril I, Breant B \& Dupouy JP 2002 Perinatal malnutrition programs sympathoadrenal and hypothalamic-pituitary-adrenal axis responsiveness to restraint stress in adult male rats. Journal of Neuroendocrinology 14 135-143. (doi:10.1046/j.0007-1331.2001.00753.x)

Levitt NS, Lambert EV, Woods D, Hales CN, Andrew R \& Seckl JR 2000 Impaired glucose tolerance and elevated blood pressure in low birth weight, nonobese, young south african adults: early programming of cortisol axis. Journal of Clinical Endocrinology and Metabolism $\mathbf{8 5}$ 4611-4618. (doi:10.1210/jcem.85.12.7039)

Linsen SE, de Wit E, de Bruijn E \& Cuppen E 2010 Small RNA expression and strain specificity in the rat. BMC Genomics 11249 . (doi:10.1186/ 1471-2164-11-249)

Meier I, Fellini L, Jakovcevski M, Schachner M \& Morellini F 2010 Expression of the snoRNA host gene gas5 in the hippocampus is upregulated by age and psychogenic stress and correlates with reduced novelty-induced behavior in C57BL/6 mice. Hippocampus 20 1027-1036. (doi:10.1002/hipo.20701)

Nemoto T, Yamauchi N \& Shibasaki T 2009 Novel action of pituitary urocortin 2 in the regulation of expression and secretion of gonadotropins. Journal of Endocrinology 201 105-114. (doi:10.1677/ JOE-08-0467)

Nemoto T, Iwasaki-Sekino A, Yamauchi N \& Shibasaki T 2010 Role of urocortin 2 secreted by the pituitary in the stress-induced suppression of luteinizing hormone secretion in rats. American Journal of Physiology. Endocrinology and Metabolism 299 E567-E575. (doi:10.1152/ajpendo. 00163.2010)

Nemoto T, Mano A \& Shibasaki T 2013 miR-449a contributes to glucocorticoid-induced CRF-R1 downregulation in the pituitary during stress. Molecular Endocrinology 27 1593-1602. (doi:10.1210/me. 2012-1357)

Nolan T, Hands RE \& Bustin SA 2006 Quantification of mRNA using real-time RT-PCR. Nature Protocols 1 1559-1582. (doi:10.1038/nprot. 2006.236)

Ochedalski T, Rabadan-Diehl C \& Aguilera G 1998 Interaction between glucocorticoids and corticotropin releasing hormone $(\mathrm{CRH})$ in the regulation of the pituitary $\mathrm{CRH}$ receptor in vivo in the rat. Journal of Neuroendocrinology 10 363-369. (doi:10.1046/j.1365-2826. 1998.00212.x)

Owen D \& Matthews SG 2007 Prenatal glucocorticoid exposure alters hypothalamic-pituitary-adrenal function in juvenile guinea pigs. Journal of Neuroendocrinology 19 172-180. (doi:10.1111/j.1365-2826. 2006.01517.x)

Raikkonen K, Pesonen AK, Heinonen K, Kajantie E, Hovi P, Jarvenpaa AL, Eriksson JG \& Andersson S 2008 Depression in young adults with very low birth weight: the Helsinki study of very low-birth-weight adults. Archives of General Psychiatry 65 290-296. (doi:10.1001/archgenpsychiatry.2007.40)

Reus VI, Peeke HV \& Miner C 1985 Habituation and cortisol dysregulation in depression. Biological Psychiatry 20 980-989. (doi:10.1016/00063223(85)90196-9)

Reynolds RM, Walker BR, Syddall HE, Andrew R, Wood PJ, Whorwood CB $\&$ Phillips DI 2001 Altered control of cortisol secretion in adult men with low birth weight and cardiovascular risk factors. Journal of Clinical Endocrinology and Metabolism 86 245-250. (doi:10.1210/jcem.86.1. 7145)

de Rooij SR, Painter RC, Phillips DI, Osmond C, Michels RP, Bossuyt PM, Bleker OP \& Roseboom TJ 2006 Hypothalamic-pituitary-adrenal axis activity in adults who were prenatally exposed to the Dutch famine. European Journal of Endocrinology 155 153-160. (doi:10.1530/eje.1. 02193)

Rumball CW, Oliver MH, Thorstensen EB, Jaquiery AL, Husted SM, Harding JE \& Bloomfield FH 2008 Effects of twinning and periconceptional undernutrition on late-gestation hypothalamicpituitary-adrenal axis function in ovine pregnancy. Endocrinology 149 1163-1172. (doi:10.1210/en.2007-1306)

Sahoo S, Klychko E, Thorne T, Misener S, Schultz KM, Millay M, Ito A, Liu T, Kamide C, Agrawal H et al. 2011 Exosomes from human CD34(+) stem cells mediate their proangiogenic paracrine activity. Circulation Research 109 724-728. (doi:10.1161/CIRCRESAHA.111.253286)

Schendel D \& Bhasin TK 2008 Birth weight and gestational age characteristics of children with autism, including a comparison with other developmental disabilities. Pediatrics 121 1155-1164. (doi:10.1542/peds.2007-1049)

Sebaai N, Lesage J, Vieau D, Alaoui A, Dupouy JP \& Deloof S 2002 Altered control of the hypothalamo-pituitary-adrenal axis in adult male rats exposed perinatally to food deprivation and/or dehydration. Neuroendocrinology 76 243-253. (doi:10.1159/000065947)

Sebaai N, Lesage J, Breton C, Vieau D \& Deloof S 2004 Perinatal food deprivation induces marked alterations of the hypothalamo-pituitaryadrenal axis in 8-month-old male rats both under basal conditions and after a dehydration period. Neuroendocrinology 79 163-173. (doi:10.1159/000078098)

Turchinovich A, Weiz L, Langheinz A \& Burwinkel B 2011 Characterization of extracellular circulating microRNA. Nucleic Acids Research 39 7223-7233. (doi:10.1093/nar/gkr254)

Viltart O, Mairesse J, Darnaudery M, Louvart H, Vanbesien-Mailliot C, Catalani A \& Maccari S 2006 Prenatal stress alters Fos protein expression in hippocampus and locus coeruleus stress-related brain structures. Psychoneuroendocrinology 31 769-780. (doi:10.1016/j.psyneuen.2006. 02.007)

Vreeburg SA, Hoogendijk WJ, van Pelt J, Derijk RH, Verhagen JC, van Dyck R, Smit JH, Zitman FG \& Penninx BW 2009 Major depressive disorder and hypothalamic-pituitary-adrenal axis activity: results from a large cohort study. Archives of General Psychiatry 66 617-626. (doi:10.1001/archgenpsychiatry.2009.50)

Wahlbeck K, Forsen T, Osmond C, Barker DJ \& Eriksson JG 2001 Association of schizophrenia with low maternal body mass index, small size at birth, and thinness during childhood. Archives of General Psychiatry 58 48-52. (doi:10.1001/archpsyc.58.1.48)

Ward AM, Syddall HE, Wood PJ, Chrousos GP \& Phillips DI 2004 Fetal programming of the hypothalamic-pituitary-adrenal (HPA) axis: low birth weight and central HPA regulation. Journal of Clinical Endocrinology and Metabolism 89 1227-1233. (doi:10.1210/jc.2003-030978)

Young EA, Lopez JF, Murphy-Weinberg V, Watson SJ \& Akil H 2000 Hormonal evidence for altered responsiveness to social stress in major depression. Neuropsychopharmacology 23 411-418. (doi:10.1016/S0893133X(00)00129-9)

Zhou Y, Spangler R, LaForge KS, Maggos CE, Ho A \& Kreek MJ 1996 Modulation of CRF-R1 mRNA in rat anterior pituitary by dexamethasone: correlation with POMC mRNA. Peptides 17 435-441. (doi:10.1016/0196-9781(96)00014-9)

Received in final form 2 December 2014

Accepted 5 December 2014

Accepted Preprint published online 5 December 2014 http://joe.endocrinology-journals.org DOI: 10.1530/JOE-14-0537
() 2015 Society for Endocrinology Printed in Great Britain 